\title{
Environmental impact of wastewater discharges from FERMENCAM
}

\author{
Noukeu Nkouakam Armelle ${ }^{1,2, ~ *}$, Priso Richard Jules ${ }^{2}$ \\ ${ }^{1}$ Department of Plant Biology and Physiology, Faculty of Sciences, University of Yaoundé I, Yaoundé Cameroon \\ ${ }^{2}$ Department of Plant Biology and Physiology, Faculty of Sciences, University of Douala, Douala, Cameroon
}

Email address:

noukeukoua@yahoo.fr (N. N. Armelle)

To cite this article:

Noukeu Nkouakam Armelle, Priso Richard Jules. Environmental Impact of Wastewater Discharges from FERMENCAM. International Journal of Environmental Protection and Policy. Vol. 2, No. 5, 2014, pp. 174-178. doi: 10.11648/j.ijepp.20140205.15

\begin{abstract}
This study aims to assess the environmental impact of wastewater discharges from FERMENCAM. Effluent and wastewater samples were collected respectively at the plant outlet and in the receiving environment, and physico-chemical analyses carried out revealed an organic pollution with a high pollution load that can be observed by phosphate levels in water at the plant outlet. Biochemical oxygen demand $\left(\mathrm{BOD}_{5}\right)$ is high at the plant outlet $(20300 \mathrm{mg}$ of $\mathrm{O}_{2} / \mathrm{L}$ ) and $16200 \mathrm{mg}$ of $\mathrm{O}_{2} / \mathrm{L}$ are found in the receiving environment. The $\mathrm{BOD}_{5} / \mathrm{COD}$ (chemical oxygen demand) ratio of effluents discharged by FERMENCAM and that of the receiving environment is 0.90 . This value is higher than 0.5 , meaning that the organic matter of both effluents is highly biodegradable. The results show that the increase in conductivity and decrease in total dissolved salts are due to an excessive mineralization of organic matters. The results show that the chlorophyll synthesis in Amaranthus viridis leaves is linked to the quality of the environment, and that is why such leaves can easily adapt to the polluted environment. In short, the wastewater impact on water quality of the receiving environment is evident, and these data will allow better environmental protection, thus promoting the development of various waterfront activities. In addition, the need for sustainable wastewater management (wastewater treatment plants, pre-treatment of industrial waters and sensitization) in the study area proves to be vital and urgent in order to improve wastewater quality and contribute to improving the state of the environment.
\end{abstract}

Keywords: Wastewater, Physico-Chemical Pollution, FERMENCAM, Environmental Impact.

\section{Introduction}

Over the past two decades, the industrialization process in Cameroon has been reflected by the increasing number of plants in major urban areas like Douala having the largest and most diverse industrial hub. Indeed, like all human activities these industrial plants generate effluents and wastes whose management is not ensured by industry proponents, thus contributing to the ecosystem imbalance which results in the degradation of nature. This is the case of surface waters polluted by different discharges, which are subjected to intensive research since the early $20^{\text {th }}$ century [ 4 , 16]. FERMENCAM is among industrial companies for which waste water management does not seem to comply with applicable regulatory requirements and environmental standards, and this situation may therefore have an impact on aquatic and terrestrial receiving environments. FERMENCAM is a food company specialized in distillery and alcoholic fermentation which discharges its effluent into a nearby downstream swamp. Although such effluents are ongoing sources of environmental pollution, there is a proliferation of lowland agricultural practices only a few meters from the outlet of the sewer system of the plant, characterized by a variety of consumable crop plants irrigated by wastewater from FERMENCAM whose growth is amazing; there are also ruderals with remarkable resilience and dominance in the area. This study aims to assess the environmental impact of wastewater discharges from FERMENCAM. More specifically, this study aims to: characterize the physico-chemical and bacteriological status of effluents discharged by FERMENCAM, compare such effluents with those collected from the nearby swamp, characterize the biological components of the Amaranthus viridis crop plant growing in the environment polluted by FERMENCAM and those from the same crop plant in an unpolluted environment. 


\section{Materials and Methods}

\subsection{Description of the Study Area}

The city of Douala is located on the banks of the Wouri River, $30 \mathrm{~km}$ from the sea, not far from the equator on the Gulf of Guinea and the study area is located in a north-west suburb at $3 \mathrm{~km}$ from Douala with latitude $4^{\circ} 06^{\prime} 45.1^{\prime \prime} \mathrm{N}$ and longitude $9^{\circ} 37^{\prime} 18.0^{\prime \prime} \mathrm{E}$. It is a marshy area of $120 \mathrm{~m} \mathrm{x} 100 \mathrm{~m}$.

\subsection{Sampling}

\subsubsection{Physico-Chemical and Bacteriological Analyses of Wastewater}

Sampling and analysis of wastewater are carried out in the following order:

- Collection of warm wastewater samples at the plant outlet (on the sewer system);

- Collection of water samples from the polluted swamp (receiving environment located behind FERMENCAM).

Samples to be used for bacteriological analyses were collected by hand immersed in wastewater, using a $100 \mathrm{ml}$ borosilicate glass flask. These samples were transported in a cooler refrigerated at $4{ }^{\circ} \mathrm{C}$ to reduce bacterial density fluctuations. Wastewater collected have undergone cytology tests and will be put in SABOURAUD, BLOOD AGAR and CHAPMAN culture media (for anaerobic staphylococci), EMB (for gram-negative bacilli). The concentration components found in the two wastewater is represented by the + sign (low concentration), ++ (average concentration), +++ (high concentration). During the analysis, the appearance, color and $\mathrm{pH}$ of the wastewater were determined.

Except temperature, $\mathrm{pH}$, electric conductivity and total dissolved salts that were collected in situ, all the other physico-chemical measurements (biochemical oxygen demand $\left(\mathrm{BOD}_{5}\right)$, chemical oxygen demand (COD), nitrates, phosphates, total suspended solids (TSS) and cadmium $\left(\mathrm{Cd}^{2+}\right.$ were conducted in the laboratory and water samples were collected in polyethylene bottles and transported to the laboratory at room temperature.

\subsubsection{Assays of Biological Components}

- Collection of Amaranthus viridis leaves in a polluted environment behind FERMENCAM;

- Collection of Amaranthus viridis leaves in an unpolluted site.

\subsection{Literature Review}

PH measurement was made in situ using a HI 991001 HANNA $\mathrm{pH} /$ thermometer, electrical conductivity was measured using a HI8733 HANNA conductivity meter, the determination of total suspended solids in water was carried out using a sintered glass membrane filtration and gravimetry.

Nitrate ions $\left(\mathrm{NO}^{3+}\right)$ are measured with the sodium salicylate assay method; orthophosphate $\left(\mathrm{PO}_{4}{ }^{3-}\right)$ is determined by using ammonium molybdate in the colorimetric assay method, COD was determined with potassium dichromate assay method; $\mathrm{BOD}_{5}$ is determined with instrumental methods derived from respirometric methods which allow to automatically follow the development of the biochemical oxygen demand during the oxidation of organic matter present in water; cadmium is determined with the atomic absorption method [15].

The assay of the biological components in Amaranthus viridis leaves involves the chlorophyll determination according to Mac Kinney method [12]; the protein, lipid and carbohydrate assays involve the calculation of water content nitrogen content determined by the Kjeldahl method, the assessment of the total lipids [5, 17], assessment of ash contents [3], assessment of the total carbohydrate content using the difference method $[1,17]$.

\section{Results}

\subsection{Characterization of Physico-Chemical and Bacteriological Status of Effluents Discharged by FERMENCAM}

Table 1. Concentrations of physico-chemical water parameters measured at the plant outlet and in the receiving environment

\begin{tabular}{|c|c|c|c|}
\hline Parameters & Plant outlet & Receiving environment & $\%$ reduction of the receiving environment \\
\hline $\mathrm{pH}$ (pH unit) & 4.5 & 4.25 & \\
\hline Conductivity ( $\mu \mathrm{s} / \mathrm{cm})$ & 4700 & 3844 & $18.21 \%$ \\
\hline Temperature (degree Celsius) & 36.5 & 28.8 & \\
\hline TDS (mg/l) & 3100 & 2542 & $18 \%$ \\
\hline $\operatorname{COD}\left(\mathrm{mg}\right.$ of $\left.\mathrm{O}_{2} / \mathrm{l}\right)$ & 22500 & 17900 & $20.44 \%$ \\
\hline BOD5 (mg of $\left.\mathrm{O}_{2} / \mathrm{l}\right)$ & 20300 & 6200 & 20.19 \\
\hline TSS (mg/l) & 100 & 170 & $-70 \%$ \\
\hline Phosphate (mg/l) & 101 & 68 & $32.6 \%$ \\
\hline Nitrate (mg/l) & 12 & 40 & $-233.33 \%$ \\
\hline Cadmium (mg/l) & 0.4229 & 0.417 & $0.142 \%$ \\
\hline
\end{tabular}


Table 2. Physical water parameters measured in different points of the study area

\begin{tabular}{lllll}
\hline Point & $\mathbf{T}^{\circ}$ & $\mathbf{p H}$ & Conductivity & TDS \\
\hline Pt 1 & $36.5^{\circ}$ & 4.5 & 4700 & 3100 \\
Pt 2 & $32.4^{\circ}$ & 5.7 & 1912 & 1087 \\
Pt 3 & $31.7^{\circ}$ & 4.4 & 1900 & 1005 \\
Pt 4 & $32.1^{\circ}$ & 4.88 & 1666 & 881 \\
Pt 5 & $34^{\circ}$ & 7.33 & 5148 & 2997 \\
Pt 6 & $34.6^{\circ}$ & 4.25 & 2002 & 1100 \\
Pt 7 & $28.8^{\circ}$ & $5.19 \pm 1.09$ & 3844 & 2542 \\
Average & $32.87 \pm 2.46$ & $<0.0001^{* * *}$ & $3024.57 \pm 1493.39$ & $1816 \pm 101$ \\
P & $<0.0001^{* * *}$ & $0.002^{*}$ & $0.003^{*}$ \\
\hline
\end{tabular}

Pt 1: Sewer outlet, Pt 2: $10 \mathrm{~m}$ from the sewer, Pt 3: $30 \mathrm{~m}$ from the sewer, Pt 4: $10 \mathrm{~m}$ from Pt3, Pt 5: Zone of confluence, Pt 6: Overflow area of the swamp, Pt 7: In the middle of the swamp.

Table 3. Bacteriological water analyzes at FERMENCAM and receiving environment outlets.

\begin{tabular}{|c|c|c|c|c|}
\hline Parameters & Water at the outlet of FERMENCAM & Concentrations & Water in the receiving environment & Concentration \\
\hline Appearance & Cloudy & & Cloudy & \\
\hline Color & Brown & & Brownish & \\
\hline $\mathrm{pH}$ & 5.5 & & 6 & \\
\hline \multirow{2}{*}{ Cytology } & Bacterial flora & + & Abundant bacterial flora & +++ \\
\hline & Yeast-form cells & +++ & Yeast-form cells & + \\
\hline \multirow{2}{*}{ Coliform gram (-) } & Gram bacillus & +++ & Gram bacillus & +++ \\
\hline & Cocci in chains & 0 & Cocci in chains & +++ \\
\hline \multirow{4}{*}{ Crops } & Spindle-like flora & +++ & Spindle-like flora & +++ \\
\hline & Krebciella spp. & + & Krebciella spp. & + \\
\hline & Streptococcus sp. & + & Streptococcus sp. & + \\
\hline & Fungal species & + & Fungal species & + \\
\hline
\end{tabular}

\subsection{Comparison of Effluents Discharged by FERMENCAM to those Collected from the nearby Swamp}

The values of the physico-chemical water parameters collected at the outlets of the plant and the receiving environment are different. Conductivity, DTS, COD and $\mathrm{BOD}_{5}$ have very high concentrations relative to TSS, phosphate, nitrate and cadmium. The reduction applied through the self-purification of the receiving environment is very low (Table 1).

The analysis of cytological parameters shows high concentration of yeast-like cells at the water outlet from FERMENCAM $(+++)$, it drops in the receiving environment
$(+)$. In both environments there is a large amount of gram bacillus (-), the presence of Krebciella spp., Streptococcus and fungal species are not abundant (Table 3).

\subsection{Characterization of the Biological Components of the Amaranthus Viridis Crop Plant Growing in the Environment Polluted by FERMENCAM and those from the Same Crop Plant in an Unpolluted Environment}

The unpolluted environment has protein contents in leaves higher than those found in the polluted environment. Moreover, the levels of carbohydrates are higher in the polluted environment than in the unpolluted environment.

Table 4. Protein, lipid, carbohydrate and water contents in $\mathrm{g} / 100 \mathrm{~g}$ of dry matters expressed in \% in the Amaranthus viridis leaves

\begin{tabular}{lllllll}
\hline Species & Environment & Proteins & Ashes & Lipids & Carbohydrates & Water content \\
\multirow{2}{*}{ Amaranthus viridis } & polluted & 6.6 & 11.3 & 12.2 & 69 & $89.88 \%$ \\
& unpolluted & 11.7 & 15 & 14.5 & 58.80 & $98.72 \%$ \\
\hline
\end{tabular}

Table 5. Results of the assay of chlorophyll in Amaranthus viridis leaves.

\begin{tabular}{|c|c|c|c|c|c|}
\hline Species & Environment & $\begin{array}{l}\text { Chlorophyll } \\
\text { a }\end{array}$ & $\begin{array}{l}\text { Chlorophyll } \\
\text { B }\end{array}$ & $\begin{array}{l}\text { Chlorophyll } \\
\text { a+b }\end{array}$ & $\mathbf{P}$ \\
\hline Amaranthus viridis & $\begin{array}{l}\text { polluted } \\
\text { unpolluted }\end{array}$ & $\begin{array}{l}17.09 \pm 0.77 \\
17.98 \pm 1.06\end{array}$ & $\begin{array}{l}31.35 \pm 1.31 \\
32.12 \pm 1.79\end{array}$ & $\begin{array}{l}48.44 \pm 2.07 \\
50.09 \pm 2.83\end{array}$ & 0.273 \\
\hline
\end{tabular}

\section{Discussion}

The temperature is very high $\left(36.5^{\circ} \mathrm{C}\right)$ compared to that of the receiving environment $\left(28.8^{\circ} \mathrm{C}\right)$ (Table 1). Reference [8] found a temperature of $52.8^{\circ} \mathrm{C}$ in FERMENCAM. High temperatures have a negative effect on aquatic life and many organisms deprived of heat regulatory mechanisms will have their vital activities slowed down $[16,9]$.

The $\mathrm{pH}$ is acidic, values measured in the different points (Table 2) are different from those found in Table 1; these variations are linked to an overdose of acid-base cleaning products [10]. This magnitude of the $\mathrm{pH}$ shift is detrimental to the environment [11]. The conductivity is very high at the source (plant outlet) and increases in certain points of the 
study area (Table 1 and 2), but it decreased in the receiving environment.

The increase in conductivity and reduction in total dissolved salts is due to the excessive mineralization of organic matters [2]. According to [6], the conductivity of a solution allows to estimate the content in total dissolved salts.

A significant correlation is observed between conductivity and TDS (Table 2). COD which is the global measurement for assessing organic pollution shows a value greater than the one of the receiving environment at the plant outlet. The $\mathrm{BOD}_{5} / \mathrm{COD}$ ratio of effluents discharged by FERMENCAM and that of the receiving environment is 0.90 . This value is higher than 0.5 , meaning that the organic matter of both effluents is highly biodegradable. The COD values studied exceed the value of $80 \mathrm{mg}$ of $\mathrm{O}_{2} / 1$ set by the WHO.

The highest values are found at the plant outlet (20 300 $\mathrm{mg}$ of $\mathrm{O}_{2} / \mathrm{L}$ ) and there are $16200 \mathrm{mg}$ of $\mathrm{O}_{2} / \mathrm{L}$ in the receiving environment. The discharge of large quantities of urban and industrial waste water in a confined space causes a considerable increase in the organic content of surface waters. High values of $\mathrm{BOD}_{5}$ according to [14] may be correlated with the magnitude of the discharges in the swamp. TSS value is higher in the receiving water than in the plant outlet (Table 1). This is due to daily discharges and their stagnation in the environment. However, high levels can prevent light penetration, reduce dissolved oxygen and limit thus the development of aquatic life.

Concentrations at the plant outlet are higher than those in the receiving environment with the exception that the level nitrate is $40 \mathrm{mg} / \mathrm{l}$ in the receiving environment (Table 1). Nitrate levels at the plant outlet are much lower than that obtained by [8] where pollution caused by FERMENCAM was very high $(65 \mathrm{mg} / \mathrm{l})$. High concentration of phosphate in the environment compared to that obtained in 2005 [8] (66.08 $\mathrm{mg} / \mathrm{l})$ is due to the fact that detergents, cleansing soap and products rich in phosphate are increasingly being used.

In natural waters, cadmium are only found in trace amounts, at levels comprised between 0.1 and $10 \mu \mathrm{g} / \mathrm{l}$. Values in Table 1 shows its low toxicity in both environments. Beyond the maximum threshold, they inhibit the growth and development [7]. At the plant outlet, waters are rich in yeast-like cells contrary to the receiving environment where they are few but where the bacterial flora is very abundant, such abundance being due to the stagnation and eutrophication of the swamp (Table 3).

The polluted environment has an impact on the water content of Amaranthus viridis leaves (Table 4). Regarding protein, lipid and carbohydrate contents in leaves (Table 4), protein contents are significantly lower in the polluted environment than those in the non-polluted environment, so are the lipid contents; on the contrary, carbohydrate content is very high in the polluted environment leading to a good photosynthetic activity of species ascribed to levels of chlorophylls, [18] shows that in the polluted environment in FERMENCAM on Zea mays, Eleusine indica and Commelina benghalensis, protein contents are significantly higher than those in the natural environment; besides, lipid and carbohydrate contents are significantly higher in the natural environment than in the polluted environment.

The results show that the synthesis of chlorophyll in Amaranthus viridis leaves is linked to the quality of the environment, but also to the sensitivity of the specie. According to [18], chlorophyll levels $(\mathrm{a}+\mathrm{b})$ of Commelina benghalensis and Alternantera sessilis leaves in FERMENCAM are lower than those found in the same organs of these species in another less polluted area. These results show that the polluted environment does not always have an impact on chlorophyll concentrations $(a+b)$, this is the case of Panicum maximum and Eichhornia crassipes having chlorophyll levels higher than those of the unpolluted environment [13].

\section{Conclusion}

This study aimed to assess the impact of wastewater discharges from FERMENCAM on the environment, especially on a nearby swamp where this company periodically discharges effluents.

Characterization results show that for most of the parameters analyzed, water pollution is evident and the WHO standard on industrial waste is often exceeded.

The average values found in TSS, $\mathrm{BOD}_{5}$ and COD allow to state that the pollutant load is essentially organic. It is indicative of a possible eutrophication of the receiving water environment. Further studies on microbial analysis, fauna and flora would confirm this eutrophication. To improve the quality of waste water and eliminate current nuisances, a large industrial waste water treatment plant is required for FERMENCAM.

\section{References}

[1] Agbor-Egbe, T. et Rickard, J.E. 1990. Evaluation of the chemical composition of fresh and stored Edible Aroids. J .sci Food Agric, 50: 487-495.

[2] Arrignon, J. 1998. Aménagement piscicole des eaux douces. 5e édition. Paris : Lavoisier. Tec. Doc.

[3] Bell, A. 1981. Influence des transformations technologiques traditionnelles sur la valeur nutritive des ignames (Dioscorea spp.) du Cameroun. Thèse doct. 3ème cycle, Université de Paris VI, $89 \mathrm{p}$.

[4] Blinda, M. 2000. Evaluation de la pollution des eaux de surface, des eaux souterraines et de l'air dans la région entre Tanger et Tétouan. DESA, $136 \mathrm{p}$.

[5] Fokou, E. 1988. Contribution à la valorisation des aliments locaux : Etude biochimique in vitro et in vivo de quelques éléments nutritifs essentiels des légumes et feuilles consommés au Cameroun. Thèse doct. 3ème cycle, Yaoundé, $168 \mathrm{p}$.

[6] Kalra, Y.P. et Maynard, D.G. 1992. Méthodes d'analyse des sols forestiers et des tissus végétaux. Rapport d'information NOR-X-319F Canada, 129 p. 
[7] Masarovicova, E., Kral'Ovak. et Lunackova, L. 2002. Negative effect of toxic metal on higher plants. In: Anke, M; Muller, R; Scharfer, U. et Stoeppler, M. (eds). Macro and trace elements, Mengen-und spuren element, Leipzig, 21 workshop, pp. 341-345.

[8] Mbouano, H.F. 2005. Evaluation de l'influence des rejets de quelques industries polluantes de la ville de Douala sur la diversité végétale : cas des industries dans le village de MINKWELE (Banlieue de Bonabéri) et ses environs, Mémoire de maîtrise, Université de Douala, 65p

[9] Meinck F., Stooff H., Kohlschütter H. 1977. Les eaux résiduaires industrielles, 2ème Ed. Masson, paris, 863 p.

[10] Merin, U., Gesan, G., Boyaval, E. et Daufin, G. 2002. Cleaning in -place in the dairy industry: criteria for reuse of caustic $(\mathrm{NaOH})$ Milk solution, 82: 357-366.

[11] Njiokou, L.J.M. 2004. Distribution spatiale de Pistia stratiotes (Araceae) dans quelques écosystèmes aquatiques de la ville de Douala, Mémoire de maitrise, Université de Douala, $60 \mathrm{p}$.

[12] Noubissi, T.A.M. 2004. Croissance et développement des plantules du palmier à huile (Elaeis guinensis jacq.) Influence de l'apport des substances minérales, Mémoire de maîtrise, Université de Douala, 41 p.
[13] Noukeu, N.A. 2009. Essai d'assainissement de l'environnement au voisinage des fermenteries du Cameroun à Boadibo (Douala), Mémoire de DEA, Université de Douala , $50 \mathrm{p}$.

[14] Priso, R.J. 1994. Contribution à l'identification des indicateurs écologiques de pollution dans les régions de Yaoundé et Douala. Thèse Doctorat 3ème Cycle, Université de Yaoundé I, $180 \mathrm{p}$.

[15] Rodier, J. 1996. L'analyse de l'eau : eaux naturelles, eaux résiduaires, eaux de mer. 8ème édition ; DUNOD, Paris, 1383 p.

[16] Sachon, G. 1980. L'industrie laitière et la production des eaux. Revue des Enil, 2ème partie, $51: 21-28$.

[17] Taffouo, V.D. 1994. Contribution à l'étude de l'influence des substances minérales sur la valeur nutritionnelle de trois plantes à racine et à tubercules amylacés. Etude comparative. Thèse doct. 3ème cycle, Université de Yaoundé I, 155 p.

[18] Tchinda, M.C. 2005. Impacts des eaux polluées sur la croissance, les teneurs en chlorophylles et les substances organiques dans les feuilles de Commelina benghalensis, Eleusine indica et Zea mays, Mémoire de maîtrise, Université de Yaoundé I et Douala, 42p. 